\title{
Traditions of Tolerance: The Long-Run Persistence of Regional Variation in Attitudes towards English Immigrants
}

\author{
DAVID FIELDING*
}

\begin{abstract}
This article builds on existing studies of the long-run persistence of geographical variation in tolerance towards other ethnicities. Using English data, the study tests whether the persistent characteristic is an attitude towards a specific ethnic group, or is an underlying cultural trait of which the attitude towards a specific group is just one expression. It finds evidence for the latter, identifying geographical variation in anti-immigrant sentiment in the twenty-first century that is correlated with patterns of immigrant settlement in the twelfth and thirteenth centuries, despite the fact that modern immigrant groups are quite different from those in the Middle Ages.
\end{abstract}

Recent evidence in economics and political science indicates substantial long-run persistence in the extent to which different ethnic groups interact co-operatively or antagonistically. ${ }^{1}$ This evidence relates to countries with long-standing patterns of ethnic diversity, and the persistence could be explained by the endurance of particular social institutions. However, it could also be explained by the intergenerational transmission of cultural norms. ${ }^{2}$ Moreover, evidence from social psychology suggests that antipathy towards other ethnic groups is a consequence of underlying traits that transcend any specific social context, ${ }^{3}$ and the persistence of prejudice could be explained by the intergenerational transmission of these underlying traits. In this case, the level of antagonism between specific ethnic groups is not just a consequence of the history and economics of the relationship between the groups, but also of more deeply rooted social forces. Addressing perceived historical grievances - 'they've taken our land/our jobs/our social benefits' - will not entirely mitigate the antagonism.

One way to test the hypothesis that ethnic intolerance is a function of persistent underlying traits is to find a case in which one ethnic minority disappears and is replaced, after some interval of time, by other minority groups. If the hypothesis is correct, then intolerance towards one minority in an earlier period is at least partly a function of characteristics that, if they persist across generations, will lead to intolerance towards other minorities in later periods. Therefore,

* Department of Economics, University of Otago (email: david.fielding@otago.ac.nz). Supplementary material for this article appears in appendices available online, along with the data used in the statistical analysis. Data replication sets are available at https://dataverse.harvard.edu/dataverse/BJPolS, and online appendices are available at http://dx.doi.org/doi:10.1017/S0007123415000575.

1 Jha 2013; Voigtländer and Voth 2013. These articles are part of a wider literature that documents evidence of the persistence of different cultural traits. For example, some of the variation in modern US state constitutions is associated with cultural heterogeneity across different groups of eighteenth-century settlers (Fischer 1989), modern US homicide rates are higher in regions where the settlers had an 'honour culture' (Grosjean 2014) and the modern cultural characteristics of former US slave states are significantly different from those of other states (Acharya, Blackwell, and Sen 2014). The slave trade changed gender ratios, so communities descended from slaves retain different attitudes towards polygyny (Dalton and Leung 2011). Likewise, the regional variation in modern Polish political preferences is correlated with the historical division of Poland between Russia, Prussia and Austria-Hungary (Grosfeld and Zhuravskaya 2013).

2 Cavalli-Sforza and Feldman 1973.

3 McFarland 2010; Thomsen, Green, and Sidanius 2008. 
the regional variation in intolerance towards the earlier minority should be correlated with variation in intolerance towards the later minorities. In this article we argue that one such case is medieval and modern England. ${ }^{4}$ In the twelfth and thirteenth centuries, England was home to a large Jewish community that had emigrated from France in the years following the Norman Conquest of 1066. However, the distribution of Jewish communities was not uniform across the country: communities were established in about thirty English towns, and Jews were largely absent elsewhere. These communities survived to the end of the thirteenth century, when all Jews were expelled from England: this was the first event of this kind in Europe, 200 years before the expulsions from Spain and Portugal. England was officially barred to Jews until 1656, and although there were probably a few Jewish families living secretly in Tudor London, there was a period of nearly 400 years during which neither the Jews nor any other minority of overseas origin established a community in England..$^{5}$ Jewish immigration in recent centuries has been limited; the modern English Jewish community represents less than 0.5 per cent of the population and is largely concentrated in the London area. On the other hand, England is now home to other ethnic minorities, mainly of Caribbean and South Asian descent (as a result of late twentieth-century immigration) and of Eastern European descent (as a result of early twenty-first-century immigration). In the most recent census, 13 per cent of English residents reported that they were born outside the United Kingdom. Thus England is more suited to a test of our conjecture than countries with long-standing ethnic minorities.

In this article we analyse regional variation in attitudes towards immigrants in twenty-first century England, and in attitudes about the far-right political parties associated with antipathy towards immigrants. We show that, conditional on socio-economic conditions and measures of social capital, tolerance towards immigrants is significantly higher in towns that welcomed medieval Jews; these towns also show less support for the far right. This suggests that there is intergenerational transmission of an underlying cultural trait that transcends the relationship between the indigenous community and any one immigrant group. However, this trait is distinct from social capital. The next section summarizes the history of the Jews in medieval England, which informs the analysis of later sections.

\section{THE JEWS IN MEDIEVAL ENGLAND}

\section{Jews in the English Economy}

Settled Jewish communities were absent from England before the Norman Conquest, ${ }^{6}$ and the first Jewry was founded in London in the late eleventh century. Tax records from the 1194 donum indicate that by the end of the twelfth century there were Jewries in over twenty English towns. ${ }^{7}$ The Jews played two key roles in the medieval English economy. ${ }^{8}$ First, ecclesiastical law prevented Christians from lending money to each other at interest, and the only interestbearing assets available were those created by contracts with Jewish financiers. Secondly, the feudal system gave the king very limited powers to raise direct taxes, and this weakened his bargaining position during frequent political conflicts with the barons. The Jews stood outside the feudal system and were vassals of the king, so he could tax them directly. Jewish tax

${ }^{4}$ Throughout this article, the term 'England' is used in its narrower geographical sense, excluding Wales and Scotland. Very little is known about the history of Jews in medieval Wales and Scotland (Skinner 2003).

${ }^{5}$ As discussed in Appendix 3, most of the French Huguenot immigration was at the end of the seventeenth century.

${ }^{6}$ Scheil 2004.

${ }^{7}$ Hillaby 2003.

${ }^{8}$ Mundill 2010. 
revenue increased the king's bargaining power, so the Jewish community became associated with royal authority.

The twelfth century Jews seem to have been able to choose where to settle; most settlements were in towns that contained a royal mint, and many lay close to a royal castle that could provide protection from anti-Semitic attacks. However, towards the end of the century the state began to regulate Jewish movement and activities. This regulation was founded on a network of towns that were already home to a substantial Jewry. Each town contained a chest (or archa) where all local contracts between Jews and Christians had to be deposited. ${ }^{9}$ Each town's chest was run by two Jewish officials and two Christian officials, who reported to the local sheriff. By the mid-thirteenth century, thirty towns housed such chests; these are listed in Table $1 .^{10}$ Although records show evidence of individual families or small groups of Jews living outside archa towns, these towns formed the hub of the Jewish economy and were probably home to the vast majority of thirteenth-century Jews. ${ }^{11}$

\section{Medieval English Anti-Semitism}

Although racially motivated attacks on individual Jews seem to have been common, ${ }^{12}$ genocidal attacks on whole Jewish communities seem to have occurred only during two periods. First, there were attacks in 1189-90 following clashes between Christians and Jews at the coronation of King Richard I; ${ }^{13}$ these attacks may also have been motivated by anti-Semitic propaganda that formed part of the mobilization for the Third Crusade. It seems that some of these attacks were instigated by groups from outside the local area: accounts of the attack at the market in Lynn implicate foreign merchants, and accounts of the attack at Stamford implicate crusader troops on their way to the Holy Land. Other attacks, such as the one at York, seem to have been organized by members of the petty nobility who had run up large debts to local Jews. Unlike the attacks in fourteenth-century Germany that form part of the study of Voigtländer and Voth, ${ }^{14}$ it is unlikely that the attacks of 1189-90 tell us much about geographical variation in the intensity of anti-Semitism among the peasantry who made up the vast bulk of the population. The same is true of the other period of genocidal violence in England, during the civil war of 1263-65, when forces loyal to the barons opposing the king attacked Jewries in many of the towns they captured. $^{15}$

After the end of the civil war, negotiations between the king and the barons resulted in measures to secure royal tax revenue from sources other than the Jews, and the king's incentive to protect English Jews diminished. A royal decree in 1290 ordered the expulsion of all Jews from England by the end of the year, although they were allowed to liquidate their assets before departure. The value of these assets was recorded by the chronicler Hugh of Kendal, ${ }^{16}$ and Table 1 shows the value of Jewish assets in each town where an archa survived until 1290; these values are reported both in pounds and as a fraction of the valuation of the whole town in

9 Brand 2003; Brown and McCartney 2005.

${ }^{10}$ For reasons discussed below, London is excluded from the table.

11 In the final 'parliament' called to organize the collection of Jewish taxes in 1287 , forty out of the forty-two provincial Jewish representatives came from the archa towns listed in Table 1 (Rokéah 2001).

12 Mundill 2010.

13 Hillaby 2003.

14 Voigtländer and Voth 2013.

15 Stacey 2003.

16 Mundill 1988. 


\begin{tabular}{|c|c|c|c|c|c|}
\hline & $\begin{array}{l}\text { Towns in the } \\
1194 \text { donum }\end{array}$ & $\begin{array}{l}\text { Towns with } \\
\text { an archa }\end{array}$ & $\begin{array}{c}\text { Jewish assets in } \\
1290(£)\end{array}$ & $\begin{array}{l}\text { Jewish assets } \div \\
\text { town assets }\end{array}$ & Modern parliamentary constituencies \\
\hline Bedford & $\bullet$ & $\bullet$ & $14^{1 / 3}$ & $7.3 \%$ & Bedford \\
\hline Berkhamstead & & 0 & & & Hertfordshire SW \\
\hline Bristol & $\bullet$ & 0 & & & Bristol E, NW, S, W \\
\hline Cambridge & 0 & 0 & $16^{2} / 3$ & $3.6 \%$ & Cambridge \\
\hline Canterbury & 0 & 0 & $85^{2} / 3$ & $14.3 \%$ & Canterbury \\
\hline Chichester & 0 & & & & Chichester \\
\hline Colchester & 0 & 0 & $38^{2} / 3$ & $14.8 \%$ & Colchester \\
\hline Coventry & $\bullet$ & & & & Coventry NE, NW, S \\
\hline Devizes/Marlborough & & ○ & & & Devizes \\
\hline Exeter & 0 & 0 & & & Exeter \\
\hline Gloucester & 0 & 0 & & & Gloucester \\
\hline Hereford & 0 & 0 & $26^{2} / 3$ & $4.4 \%$ & Hereford (2005), Hereford \& Herefordshire S (2010) \\
\hline Huntingdon & & 0 & & & Huntingdon \\
\hline Ipswich & & $\mathbf{0}$ & $7 / 3$ & $1.1 \%$ & Ipswich \\
\hline Leicester & & 0 & & & Leicester E, S, W \\
\hline Lincoln & $\bullet$ & 0 & & & Lincoln \\
\hline Northampton & 0 & 0 & $50^{2} / 3$ & $18.8 \%$ & Northampton N, S \\
\hline Norwich & 0 & 0 & $47^{3}$ & $5.0 \%$ & Norwich N, S \\
\hline Nottingham & 0 & 0 & $13^{1 / 3}$ & $3.6 \%$ & Nottingham E, N, S \\
\hline Oxford & 0 & 0 & 100 & $10.9 \%$ & Oxford E, Oxford W \& Abingdon \\
\hline Stamford & & 0 & $13^{1 / 3}$ & $3.7 \%$ & Grantham \& Stamford \\
\hline Sudbury & & 0 & 5 & $\mathrm{n} / \mathrm{a}$ & Suffolk S \\
\hline Wallingford & $\bullet$ & 0 & & & Wantage \\
\hline Warwick & 0 & 0 & & & Warwick \& Leamington \\
\hline Wilton & & 0 & & & Salisbury \\
\hline Winchester & $\bullet$ & 0 & 44 & $8.5 \%$ & Winchester \\
\hline Worcester & 0 & 0 & & & Worcester \\
\hline York & 0 & 0 & $243^{2} / 3$ & $15.0 \%$ & York (2005), York Central (2010), York Outer (2010) \\
\hline
\end{tabular}

Source: Hillaby and Hillaby 2013; Mundill 1988. 
the 'Lay Subsidy' tax accounts of 1334. The largest fractions are in Northampton (19 per cent), Colchester (15 per cent) and York (15 per cent).

\section{England after the Expulsion}

There seems to have been little immigration into England between the end of the thirteenth century and the end of the seventeenth century. Documentary evidence indicates that following the expulsions from Spain and Portugal at the end of the fifteenth century, a small and secret Sephardic Jewish community established itself in London. ${ }^{17}$ However, only a tiny minority of people in Tudor England would ever have met a Jew, and literature of that period that featured Jews was set in continental Europe, for example in plays such as The Jew of Malta and The Merchant of Venice. The persecution of Jews by continental Catholic states elicited the sympathy of some English Reformation leaders, and the official ban on Jews was finally lifted by the Puritan government in 1656. However, this did not lead to immigration on a large scale, since the original Sephardic population resettled in Eastern Europe. The 2010 census indicates that Jews make up 1.75 per cent of the population of London and 0.25 per cent of the population of the rest of England.

Nevertheless, from the end of the seventeenth century onwards, other ethnic minorities entered England: first the French Huguenots (discussed in more detail in Appendix 3); then in the twentieth century groups from different parts of the former British Empire, especially the Caribbean and South Asia; and finally in the twenty-first century groups from the eastern countries of the European Union. The 2010 census indicates that around 13 per cent of English residents were born outside the United Kingdom; 13 per cent are non-white; 5 per cent are Muslim; and 2 per cent are Hindu or Sikh. Today, the Muslim minority in particular is viewed with suspicion by a large proportion of the population: only 30 per cent of respondents in the 2003 British Social Attitudes Survey (BSA) believed that British Muslims were committed to the country, and 52 per cent thought that Muslim immigration was a threat to the country's identity. ${ }^{18}$

\section{INITIAL CONDITIONS AND THE PERSISTENCE OF PREJUDICE}

How might the geographical variation in modern attitudes towards minority groups be associated with medieval Jewish settlement? As noted above, the location of genocidal attacks is unlikely to tell us much about the geographical variation in the intensity of medieval English anti-Semitism, ${ }^{19}$ but the location of archae could be more informative, since they were created in towns that were already home to large Jewish communities. Anti-Semitism in these towns might have been less intense than average, either because the original pattern of settlement was determined by the attitude of people in the towns that the first Jewish immigrants visited, or because close personal contact with Jews mitigated existing prejudices. Therefore, we frame our hypothesis about the persistence of prejudice as follows.

HyPOTHESIS 1: The intensity of antipathy towards modern minority groups in a town is negatively correlated with the presence of a medieval archa.

17 Katz 1994.

18 McLaren and Johnson 2007.

19 The locations of these attacks are noted in Hillaby (2003) and Stacey (2003). When an indicator variable for the presence of an attack is added to the models presented below, the estimated coefficient is insignificantly different from zero. 
For such a correlation to be possible, the following three conditions must hold.

1. Contact with medieval English Jews was associated with lower levels of prejudice, and prejudice was lower, on average, in towns with Jewish communities.

2. This geographical variation persisted across many centuries, despite the major social and economic changes during the intervening time, and despite the substantial inter-town migration.

3. The persistent characteristic is broader in scope than anti-Semitism, and can be manifested in antipathy towards a range of different immigrant minority groups.

In this section we discuss theory and evidence from sociology and social psychology that suggest the possibility that these three conditions hold and that Hypothesis 1 is correct. The following section then presents a test of the hypothesis.

\section{Condition 1: Personal Contact and Prejudice in Medieval England}

In social psychology, the seminal work on the effect on prejudice of personal contact with members of an out-group was conducted by Allport. ${ }^{20}$ Allport argues that whether contact increases or reduces prejudice depends on context, and the subsequent literature on 'intergroup contact theory' identifies a number of characteristics that are associated with a reduction in prejudice. Such characteristics include equal social status between members of the in-group and out-group and a lack of competition between them. ${ }^{21}$ Although Allport tends not to be cited in the literature on the persistence of prejudice, the results in this literature are consistent with intergroup contact theory. For example, Jha finds that the intensity of Hindu-Muslim conflict in modern India depends on the historical level of economic competition between the groups. ${ }^{22}$ Also, Voigtländer and Voth find not only that regional variation in the level of anti-Semitism in Nazi Germany is correlated with the variation in fourteenth-century Germany, but also that a large part of the fourteenth-century variation is explained by observable town characteristics. ${ }^{23}$ For example, among those towns with Jewish communities, genocidal events during the Black Death were significantly more likely to happen in towns where Jews had greater economic prominence (and therefore possibly represented more of a threat to competitors).

Medieval Jewish communities were much less widespread in twelfth- to thirteenth-century England than in fourteenth-century Germany, and the English towns with Jewries were more economically homogenous: for example, almost all of the English Jewries were in market towns. One might then expect that among towns with Jewries, there was more homogeneity in the level of anti-Semitism in England than in Germany. But was this level higher or lower than in the wider English population? Did intergroup contact increase or reduce prejudice? There are some reasons to suppose that intergroup contact may have reduced prejudice. First, the specialized economic role of Jews is likely to have mitigated intergroup economic competition in twelfth- to thirteenth-century England, and basic resources were not as scarce as during the Black Death. The most frequent context for contact between Jews and ordinary Christians was at the market, where the Jews were customers. Secondly, English common law explicitly gave Jews a social status equal to that of most of the Christians around them: all Jews were serfs, distinguished from other serfs only in that the Jews owed their allegiance directly to the king.

20 Allport 1954.

21 Surveys of the intergroup contact literature include Dovidio, Glick, and Rudman (2005), Pettigrew and Tropp (2006), and Pettigrew and Tropp (2012).

22 Jha 2013.

23 Voigtländer and Voth 2013. 
Very few medieval historians refer to intergroup contact theory when discussing evidence about attitudes towards English Jews, but one exception is Langmuir, ${ }^{24}$ who reviews the evidence on prejudice and intergroup contact in medieval England. In summary, he states, 'The majority of the little evidence that there is suggests that it was primarily those who lived in close contact with Jews who were friendly with them. ${ }^{25}$ To the extent that there is any evidence in the historical record, it suggests that intergroup contact had a positive effect. We might then expect the presence of a Jewish community in a town to be associated with less prejudice, on average. This would be consistent with recent research that shows intergroup contact reduces anti-immigrant sentiment in modern Europe. ${ }^{26}$

In the argument above, the association between the presence of a medieval Jewish community and the level of prejudice is interpreted as a treatment effect: the arrival of Jews changed the attitudes of their new neighbours. However, the association could also have arisen from a selection effect: there could have been some pre-existing variation across towns in the level of prejudice towards out-groups, and it is possible that Jews chose to settle in places where the level of prejudice was lower. There is too little data from the twelfth and thirteenth century to be able to quantify the relative size of the treatment and selection effects, but it is important to remember that the existence of a treatment effect is not a necessary condition for a systematic correlation between the presence of a local Jewish community and the level of prejudice.

\section{Condition 2: The Intergenerational Persistence of Regional Variation in Prejudice}

The seminal work on the intergenerational transmission of cultural characteristics was conducted by Cavalli-Sforza and Feldman, ${ }^{27}$ who developed a mathematical modelling framework to predict the level of persistence of variation between and within communities. One general result from this type of model is that the highest levels of persistence are generated by many-to-one transmission mechanisms (such as imitation of one's peers), and the lowest levels of persistence are generated by one-to-one transmission mechanisms (such as parental influence).

How plausible are these theoretical models as explanations of the persistence of specific cultural characteristics over many generations? There is some supporting evidence in empirical studies of correlations in characteristics across two or three generations, including correlations in the strength of religious identity, ${ }^{28}$ but data over many generations do not exist. An alternative approach to exploring the empirical plausibility of different intergenerational cultural transmission mechanisms is to employ agent-based models. Agent-based models use computer simulation techniques to explore the interaction of individual 'agents' who are described by simple algorithms that determine whether, for example, an agent modifies her own characteristics in response to the characteristics of her neighbours. ${ }^{29}$ It turns out that simple algorithms for individual behaviour can generate very complex population dynamics. In political science, several agent-based model studies explore the potential for the intergenerational persistence of differences in cultural characteristics across different locations. ${ }^{30}$ However, the study

24 Langmuir 1963.

25 See Langmuir 1963, 222. That such friendships did exist is attested in critical comments by anti-Semitic chroniclers about Christians who tried to protect their Jewish friends. Such chroniclers include Richard of Devizes and Matthew Paris, who criticized individuals (e.g., Richard, Earl of Cornwall), religious groups (e.g., the Friars Minor) and even whole towns (e.g., Winchester). See Bale 2000; Menache 1997.

26 Schneider 2008; Schlueter and Scheepers 2010.

27 Cavalli-Sforza and Feldman 1973. See also Cavalli-Sforza 1981.

28 Cavalli-Sforza et al. 1982.

29 Epstein and Axtell 1996.

30 Axelrod 1997; Ehrlich and Levin 2005. 
most directly relevant to our article is Iannaconne and Makowsky's. ${ }^{31}$ The purpose of their study is to explain a well-documented social phenomenon in the United States: that regional variation in religious beliefs has persisted over many generations, despite high levels of interregional migration. In the Iannaconne-Makowsky model, each agent is located at a different point in space. At the beginning of each period, an old generation dies and a new one is born, each new agent appearing at the same point as her parent and inheriting a set of characteristics from that parent. There is then a certain probability that the agent will be relocated to a different point. ${ }^{32}$ The relocation may mean that the agent's characteristics differ from the mean characteristics of her neighbours, in which case the agent must decide whether to maintain her inherited characteristics or to change so as to resemble her neighbours more closely. Different parameterizations of the model make such a change more or less likely. Iannaconne and Makowsky show that if the propensity to change is high enough, then differences in mean characteristics across regions can persist over many generations, even if the probability of relocation is quite high.

Overall, the literature on intergenerational cultural transmission suggests that the key determinant of the magnitude of persistence in regional variation is likely to be the strength of many-to-one assimilation effects relative to parental inheritance effects. While there is no direct evidence on the relative strength of such effects in Western Europe over the last 800 years, there is evidence of the persistence of regional variation in some cultural characteristics over similar time horizons. For example, Guiso, Sapienza and Zingales show that the regional variation in social capital in Italy has persisted from the Middle Ages to the present day, ${ }^{33}$ Nunn and Wantchekon show that there is less social capital in places where local people were victims of the slave trade, ${ }^{34}$ and Alesina, Giuliano and Nunn show that the international geographical variation in gender norms associated with different types of subsistence agriculture persisted through the Industrial Revolution and explains some of the modern geographical variation in the status of women. ${ }^{35}$ Such persistence suggests that many-to-one assimilation effects can be relatively strong, in which case the persistence of regional variation in the intensity of prejudice is also possible.

\section{Condition 3: Generalized Versus Specific Prejudice}

Our hypothesis involves not just the persistence of regional variation in the intensity of prejudice towards a specific out-group, but persistence in a more general form of prejudice that is independent of specific social contexts and finds expression in antipathy towards different groups at different times. The possibility of this type of persistence is suggested by evidence from social psychology, which indicates that antipathy towards a specific out-group does not occur in isolation from other psychological traits. There are limits to cognitive dissonance, and antipathy towards out-groups is connected with other traits such as authoritarianism and social dominance. Also, when several different out-groups exist, antipathy towards one group is highly correlated with antipathy towards the others, so psychologists such as McFarland speak

31 Iannaconne and Makowsky 2007.

32 In Iannaconne and Makowsky's baseline model, the location of the new point is completely random. In other words, the factors causing people to migrate (such as finding a new job) are entirely unconnected to their cultural characteristics. If relocation is not random - for example, if an agent is more likely to relocate to a region with characteristics more closely resembling her own - then the persistence of interregional variation in characteristics can be even stronger.

33 Guiso, Sapienza, and Zingales 2008.

34 Nunn and Wantchekon 2009.

35 Alesina, Giuliano, and Nunn 2013. 
of 'generalized prejudice'. ${ }^{36}$ In medieval England, the presence of Jews in a town could have been associated with a specific treatment effect: close association with this particular out-group reduced prejudice towards them. This could have made it psychologically more difficult to maintain antipathy towards out-groups in general. ${ }^{37}$ It could also have made it more difficult to maintain the traits interconnected with prejudice, such as authoritarianism and social dominance. These changes in the nexus of psychological traits would then have been transmitted to the next generation. Many generations later, the traits would find expression in attitudes towards other specific out-groups. Alternatively, the presence of Jews in a town may have reflected a selection effect: the inhabitants of that town already had a relatively low level of generalized prejudice, manifested as a less intense anti-Semitism in the twelfth and thirteenth centuries and as a more liberal attitude towards minority groups in the twenty-first century.

\section{MODELLING MEASURES OF TOLERANCE AND THEIR CORRELATES}

\section{Data}

Our test of Hypothesis 1 involves modelling different measures of individual attitudes from modern survey data, conditional on the characteristics of individuals and the characteristics of the places in which they live, one of which is an indicator variable for the presence of an archa in the thirteenth century. Several different large-scale surveys contain responses to questions about attitudes towards immigration and associated attributes such as support for far-right political parties: these include the BSA, the British Citizenship Survey (BCS) and the British Election Study (BES), which has been conducted during every general election since 1963. One limitation of the BSA and the BCS for our purposes is that they are based on face-to-face interviews with respondents selected in a stratified sampling design. The different waves of the BSA have been based on 200-300 sample points, and the BCS was based on around 1,500 sample points. Each sample point is a postcode cluster or ward. ${ }^{38}$ The sampling design means that the sample points are representative of broad regions, but not necessarily of smaller geographical areas. In the BSA, some English towns are not sampled at all.

The 2005 and 2010 waves of the BES are different, including an internet-based survey of a random sample of the whole electoral roll that includes respondents from every parliamentary constituency in England, Scotland and Wales. ${ }^{39}$ The 2005 BES comprises 7,793 respondents across 626 constituencies; the 2010 BES comprises 16,814 respondents across 630 constituencies. The size of towns varies, so some towns cover more than one constituency and others form only part of a constituency, but it is possible to match archa towns to constituencies in the way illustrated in Table 1. We define an archa constituency as one that includes part or all of an archa town. All of the towns in Table 1 have grown considerably over the last 700 years, so the constituencies cover a geographical area that is broader than the small settlements inhabited by medieval Jews. Nevertheless, if each town has a unique culture that is preserved as it grows, we ought to be able to identify the effect of a medieval Jewish presence on modern

36 McFarland 2010; Thomsen, Green, and Sidanius 2008.

37 For example, it could have changed attitudes about the Turks and Saracens. Very few people ever met a Turk or Saracen, but their prominence in popular culture is reflected in the appearance of their severed heads on so many inn signs.

38 The ward is the basic geographical unit in the UK Census, and the basic geographical unit in elections: parliamentary constituencies are formed as aggregations of wards. A ward comprises 5,000-6,000 people; there are around 10,000 wards in the United Kingdom.

39 See www.essex.ac.uk/bes/ and www.bes2009-10.org. 
attitudes by comparing the constituencies containing all or part of an archa town with the other constituencies. However, London is excluded from Table 1 and from our sample. Modern London comprises seventy-one constituencies, most of which are tens of miles away from the small medieval city inhabited by the Jews, and we will not assume that there is any cultural continuity between medieval London and the modern mega-city. The next largest archa town is Bristol, which comprises four constituencies and is included in our sample.

Our strategy then is to model responses to questions in the 2005 and 2010 waves of the BES conditional on respondent characteristics and on the characteristics of their constituencies. One of the constituency characteristics, Archa-town, equals 1 if the respondent lives in a constituency containing an archa town, and 0 otherwise. (Replacing Archa-town with an indicator defined by the towns in the 1194 donum, or by the towns with archae surviving to 1290 , produces results very similar to the ones reported below. ${ }^{40}$ ) The results are based on 2005 and 2010 samples, which comprise respondents from all English constituencies outside London.

The two waves of the survey include questions related to attitudes towards foreign immigrants and far-right political parties. The questions we use are as follows.

Questions relating to attitudes towards foreign immigrants. There are several different questions relating to foreign immigrants in the two waves of the BES. One of the 2010 questions that relates specifically to attitudes is: 'Which, if any, of the following words describe your feelings about immigration?'

Respondents could choose up to four of the following words: 'angry', 'happy', 'disgusted', 'hopeful', 'uneasy', 'confident', 'afraid' or 'proud' (which were randomly rotated in each respondent's survey), plus 'no feelings' and 'don't know'. We define a binary variable, Immigrant-feeling-10, which equals 1 if the respondent ticked the 'angry' or 'disgusted' box (or both), and 0 otherwise. ${ }^{41}$ This variable is designed to identify the respondents whose feelings towards immigrants are the most antipathetic. The 2005 wave does not include this question, but at the beginning of the survey respondents were asked: 'As far as you're concerned, what is the single most important issue facing the country at the present time?'. There was a free-text answer box. We define a binary variable, Immigrant-issue-05, which equals 1 if the respondent's answer included 'immigrants', 'asylum-seekers' or associated words, and 0 otherwise. In the context of the 2005 general election, it is very unlikely that respondents with positive feelings towards immigrants would think immigration was the most important issue facing the country. If there is any intergenerational transmission of attitudes towards immigrants, we should find that the proportion of respondents for whom Immigrant-feeling-10 $=1$ or Immigrant-issue-05 $=1$ is significantly lower in constituencies containing archa towns. The BES contains a number of other questions about immigration and related issues; in Appendix 2 we report results using these alternative measures, which are very similar to the results reported in the main text.

40 Conditional on archa-town, the asset values in Table 1 are not a significant determinant of attitudes.

41 An alternative modelling strategy is to further divide the not-angry-or-disgusted group and create a multinomial response variable. Less than 4 per cent of the sample reported being happy or proud, so creating a separate category for this group does not make sense, but it is possible to distinguish between (1) those who are uneasy or afraid but not angry or disgusted (23 per cent of the sample) and (2) those who are neither uneasy, nor afraid, nor angry, nor disgusted (19 per cent of the sample). Analysis of this multinomial variable along the lines described below does not produce a significant archa town effect on the probability of falling into category (1) relative to the probability of falling into category (2). 
Questions relating to support for far-right political parties. Questions about feelings towards immigrants necessarily involve some subjectivity. A somewhat more concrete set of questions in the two waves of the BES relates to the respondents' support for the two political parties on the far right: the United Kingdom Independence Party (UKIP) and the British National Party (BNP). Both of these parties' manifestos include substantial restrictions on immigration. ${ }^{42}$ In the 2010 wave of the BES, respondents were asked to take part in an imaginary Alternative Vote (AV) ballot in which they ranked candidates from the Conservative, Labour, Liberal Democrat, Green and Respect parties, plus the UKIP and the BNP: 'Thinking about this Ballot Paper, please... rank the parties in order of preference... Please number as many or as few choices as you wish'.

We define an ordinal variable UKIP-rank-10, which equals 6 if the UKIP is ranked first, 5 if it ranked second and so on down to 0 if the UKIP is ranked seventh or unranked; ${ }^{43}$ the variable BNP-rank-10 is constructed in an analogous way. The 2005 wave of the BES does not include an $\mathrm{AV}$ ballot, but it does include the following question: 'On a scale that runs from 0 to 10 , where 0 means strongly dislike and 10 means strongly like, how do you feel about the United Kingdom Independence Party (UKIP)?'. We use the response to this question, denoted UKIP-feeling-05, as an alternative measure of the strength of support for UKIP. (No equivalent measure is available for the BNP.) If there is any intergenerational transmission of anti-immigrant sentiment, and if such sentiment translates into support for a far-right party, then we should find that the values of the three party support variables are significantly lower in constituencies containing archa towns. The two waves of the survey contain other questions about party support, which are discussed in Appendix 2; results using these alternative measures are similar to the ones reported in the main text. Appendix 2 also contains a constituency-level analysis of the actual vote for the BNP and UKIP in the 2010 election, the results of which are consistent with those in the main text.

Table 2 provides information about the strength of the association between Archa-town and our five attitude variables. It can be seen that the proportion of respondents for whom Immigrantfeeling-10 $=0$ or Immigrant-issue-05 $=0$ is larger in the archa constituencies than in other constituencies. Similarly, the proportion of respondents with low values of UKIP-rank-10, BNP-rank-10 and UKIP-feeling-05 is larger in the archa constituencies. In other words, the archa constituencies show less antipathy towards immigrants and less support for far-right parties. Pearson $\chi^{2}$ test statistics indicate that these differences are significant at the 1 per cent level for all variables except UKIP-feeling-05, for which the difference is significant at the 5 per cent level.

However, the Archa-town variable may be correlated with other individual or constituency characteristics that influence attitudes, and in order to test Hypothesis 1 we need to control for these characteristics. The individual controls taken from the BES include the respondent's household income (Income), whether the respondent or his/her partner receives a state benefit (If-beneficiary), whether the respondent has a university degree (If-graduate), whether the respondent has no formal qualifications (If-low-quals), the respondent's marital status (If-widowed, If-separated, If-divorced, If-single - the default category comprises respondents who are married), whether there are children in the respondent's household (If-kids), gender (If-female), whether the respondent identifies as a member of an organized religious group (If-religious), the respondent's age in years (Age) along with $\mathrm{Age}^{2}$, two measures of trust in others (Trust-1 and Trust-2), one measure of self-reported life satisfaction (Happiness) and one measure of the respondent's satisfaction with the political system (Satisfaction). The Trust and Happiness variables are measured on a ten-point scale, and the Satisfaction variable on a

${ }^{42}$ Carey and Geddes 2010.

${ }^{43}$ In an $\mathrm{AV}$ ballot, the consequences for a party of leaving it unranked are the same as ranking it last. 
TABLE 2 Cross-Tabulations for Archa-Town and Responses in the BES

\begin{tabular}{|c|c|c|}
\hline & Archa-town $=0$ & Archa-town $=1$ \\
\hline $\begin{array}{l}\text { Immigrant-feeling-10 }=0 \\
\text { Immigrant-feeling-10 }=1 \\
\text { Pearson Test }\end{array}$ & $\begin{array}{c}3,498(41 \%) \\
5,047(59 \%) \\
\chi^{2}(1) \stackrel{=}{=} 34.3(\mathrm{p}<0.01)\end{array}$ & $\begin{array}{l}398(52 \%) \\
370(48 \%)\end{array}$ \\
\hline $\begin{array}{l}B N P-\text { rank }-10=0 \\
B N P \text {-rank- } 10=1 \\
B N P-\text { rank- } 10=2 \\
B N P \text {-rank- } 10=3 \\
B N P \text {-rank } 10=4 \\
B N P-\text { rank- } 10=5 \\
B N P \text {-rank-10 }=6 \\
\text { Pearson test }\end{array}$ & $\begin{array}{c}5,088(74 \%) \\
549(8 \%) \\
309(4 \%) \\
261(4 \%) \\
330(5 \%) \\
228(3 \%) \\
140(2 \%) \\
\chi^{2}(6)=26.9(\mathrm{p}<0.01)\end{array}$ & $\begin{array}{c}497(82 \%) \\
44(7 \%) \\
18(3 \%) \\
20(3 \%) \\
16(3 \%) \\
6(1 \%) \\
6(1 \%)\end{array}$ \\
\hline $\begin{array}{l}U K I P-\text { rank-10 }=0 \\
U K I P \text {-rank-10=1 } \\
U K I P \text {-rank-10 }=2 \\
U K I P \text {-rank-10=3 } \\
U K I P \text {-rank-10 }=4 \\
U K I P-\text { rank-10 }=5 \\
U K I P \text {-rank-10 }=6 \\
\text { Pearson test }\end{array}$ & $\begin{array}{c}2,303(33 \%) \\
481(7 \%) \\
591(9 \%) \\
799(12 \%) \\
1,143(17 \%) \\
1,121(16 \%) \\
484(7 \%) \\
\chi^{2}(6)=25.9(\mathrm{p}<0.01)\end{array}$ & $\begin{aligned} & 242(40 \%) \\
& 56(9 \%) \\
& 54(9 \%) \\
& 67(11 \%) \\
& 91(15 \%) \\
& 75(12 \%) \\
& 23(4 \%)\end{aligned}$ \\
\hline $\begin{array}{l}\text { Immigrant-issue-05 }=0 \\
\text { Immigrant-issue-05 }=1 \\
\text { Pearson test }\end{array}$ & $\begin{array}{c}3,308(75 \%) \\
1,095(25 \%) \\
\chi^{2}(1)=10.3(\mathrm{p}<0.01)\end{array}$ & $\begin{array}{r}349(82 \%) \\
76(18 \%)\end{array}$ \\
\hline $\begin{array}{l}\text { UKIP-feeling-05 }=0 \\
\text { UKIP-feeling-05 }=1 \\
\text { UKIP-feeling-05 }=2 \\
\text { UKIP-feeling-05 }=3 \\
\text { UKIP-feeling-05 }=4 \\
\text { UKIP-feeling-05 }=5 \\
\text { UKIP-feeling-05 }=6 \\
\text { UKIP-feeling-05 }=7 \\
\text { UKIP-feeling-05 }=8 \\
\text { UKIP-feeling-05 }=9 \\
\text { Pearson test }\end{array}$ & $\begin{array}{c}1,445(39 \%) \\
383(10 \%) \\
321(9 \%) \\
293(8 \%) \\
482(13 \%) \\
253(7 \%) \\
195(5 \%) \\
168(4 \%) \\
82(2 \%) \\
116(3 \%) \\
\chi^{2}(9)=16.9(\mathrm{p}=0.05)\end{array}$ & $\begin{array}{r}177(48 \%) \\
28(8 \%) \\
27(7 \%) \\
29(8 \%) \\
44(12 \%) \\
16(4 \%) \\
22(6 \%) \\
13(4 \%) \\
6(4 \%) \\
7(2 \%)\end{array}$ \\
\hline
\end{tabular}

four-point scale. ${ }^{44}$ The constituency controls include population density measured as residents per hectare (Density), the fraction of ethnic minority residents in the constituency (Minority), and the fraction of voters in the county supporting UK membership of the European Economic Community in the 1975 referendum (Membership). ${ }^{45}$ The Trust, Happiness, Satisfaction and

44 Trust-2 and Happiness are not reported in the 2005 BES.

45 The positive association between attitudes towards immigrants and income/employment status/education is a common finding in the empirical literature (Becchetti, Rossetti, and Castriota 2010; DiGiusto and Jolly 2009; Dustman and Preston 2001, 2007; Fertig and Schmidt 2011; Gang, Rivera-Batiz, and Yun 2002; Hainmueller and Hiscox 2010; Malchow-Møller et al. 2008; Malchow-Møller et al. 2009; Miguet 2008; Miguet and Müller 2007; O'Rourke and Sinnot 2006; Ortega and Polavieja 2012; Pettigrew, Wagner, and Christ 2007; Raijman and Semyonov 2004; Rustenbach 2010). Miguet and Miller (2007) and Rustenbach (2010) also find a positive association with social capital, while Dustman and Preston (2001), Facchini, Mayda, and Mendola (2013), and Rajman and Semyonov (2004) find that religious affiliation is significant. Some studies find that age, gender and 
Membership variables control for social capital and political liberalism as distinct from attitudes towards out-groups in the community. Descriptive statistics and further details about the measurement of the variables appear in Appendix 1. Since archa towns are mainly located in the south and east of England, we also include indicator variables for the broad census region in which the constituency is located: North-East, North-West, Yorkshire-Humberside, WestMidlands, East-Midlands, East, South-West and South-East.

\section{Results}

In order to see whether the differences in Table 2 are robust to conditioning on other characteristics, we fit a regression equation for each of the five attitude variables conditional on Archa-town and the control variables. The attitude variables Immigrant-feeling-10 and Immigrant-issue-05 are binary, so it is appropriate to use a probit model; the variables $B N P$-rank-10 and UKIP-rank-10 are ordinal, so it is appropriate to use an ordered-probit model; the variable UKIP-feeling-05 is distributed on a 0-10 scale, so it is appropriate to use a tobit model. We have samples of individuals within constituencies, so it is appropriate to allow for constituency-level random effects, and Tables 3 and 4 report the estimated coefficients in random-effects probit, ordered-probit and tobit models, as appropriate. ${ }^{46}$ Table 3 reports results pertaining to the $2010 \mathrm{BES}$, while Table 4 reports results pertaining to the 2005 BES. The tables also include t-ratios and probit marginal effects. (In the case of the orderedprobit models, the marginal effect is for the probability of transition from the lowest category to a higher one.) The sample sizes are reported at the bottom of each table; these vary slightly within each wave of the BES, because some respondents did not answer all of the survey questions. $^{47}$

Tables 3 and 4 show some similarities in the results for the different attitudinal variables. University graduates are significantly less likely (and those with the lowest levels of educational achievement are significantly more likely) to express anti-immigrant sentiment or to support for a far-right party. Support for far-right parties is significantly negatively associated with income. These income and education effects are consistent with the results of previous studies of attitudes towards immigrants. For some attitudinal variables there is a significantly negative population density effect, which is also consistent with previous studies. Respondents identifying with an organized religious group are significantly more likely to express anti-immigrant sentiment or to support a far-right party. Respondents who are single are significantly less likely to express anti-immigrant feelings; however, this does not correspond to a significant difference in their level of support for far-right parties. The presence of children in the household, beneficiary status and the size of the ethnic minority population are never statistically significant. The insignificance of the Minority variable might be a consequence of

marital status are significant determinants of attitudes, but the directions of the effects vary across studies. The small literature on support for the BNP and UKIP finds income, employment and education effects that are consistent with these parties' opposition to immigration (Borisyuk et al. 2007; Bowyer 2008; Cutts, Ford, and Goodwin 2011; Ford and Goodwin 2010; Whitaker and Lynch 2011).

46 The estimates were produced in Stata 13 using the xtprobit, xtoprobit and xttobit commands. The coefficients on the regional indicator variables are not reported, but are available on request. For BNP-rank-10 the estimated variance of the random effect is zero, so the results are for a pooled ordered-probit model with errors clustered at the constituency level.

${ }^{47}$ On average, there are twenty respondents per constituency in the Immigrant-feeling-10 model, sixteen respondents per constituency in the other Table 3 models, eleven respondents per constituency in the Immigrantissue-05 model and nine respondents per constituency in the UKIP-feeling-05 model. Archa constituencies account for just over 8 per cent of the total observations in both the 2010 and 2005 samples. 
TABLE 3 Determinants of Responses to Questions in the 2010 BES

\begin{tabular}{|c|c|c|c|c|c|c|c|c|c|}
\hline & \multicolumn{3}{|c|}{ Immigrant-feeling-10 } & \multicolumn{3}{|c|}{ BNP-rank-10 } & \multicolumn{3}{|c|}{ UKIP-rank-10 } \\
\hline & \multicolumn{3}{|c|}{ Probit } & \multicolumn{3}{|c|}{ Ordered probit } & \multicolumn{3}{|c|}{ Ordered probit } \\
\hline & coeff. & $t$ ratio & m.e. & coeff. & $t$ ratio & m.e. & coeff. & $t$ ratio & m.e. \\
\hline Archa-town & -0.191 & -3.79 & -0.067 & -0.259 & -4.43 & -0.077 & -0.176 & -3.54 & -0.060 \\
\hline Income & -0.061 & -0.41 & -0.021 & -0.567 & -3.27 & -0.169 & -0.541 & -3.85 & -0.185 \\
\hline If-kids & 0.034 & 0.90 & 0.012 & -0.031 & -0.73 & -0.009 & -0.036 & -1.00 & -0.012 \\
\hline if-beneficiary & 0.012 & 0.21 & 0.004 & 0.096 & 1.59 & 0.029 & 0.013 & 0.25 & 0.005 \\
\hline If-graduate & -0.498 & -14.43 & -0.173 & -0.373 & -8.99 & -0.111 & -0.325 & -10.01 & -0.112 \\
\hline If-low-quals & 0.138 & 3.89 & 0.048 & 0.120 & 3.51 & 0.036 & 0.103 & 3.59 & 0.036 \\
\hline If-widowed & -0.016 & -0.20 & -0.005 & 0.085 & 0.98 & 0.025 & 0.120 & 1.87 & 0.041 \\
\hline If-separated & -0.047 & -0.46 & -0.016 & 0.058 & 0.51 & 0.017 & -0.031 & -0.36 & -0.012 \\
\hline If-divorced & -0.116 & -2.30 & -0.040 & -0.030 & -0.55 & -0.009 & -0.022 & -0.49 & -0.008 \\
\hline If-single & -0.106 & -2.36 & -0.037 & -0.091 & -1.77 & -0.027 & 0.005 & 0.13 & 0.002 \\
\hline If-female & -0.016 & -0.58 & -0.005 & -0.235 & -7.51 & -0.070 & -0.125 & -4.94 & -0.043 \\
\hline If-religious & 0.198 & 6.94 & 0.069 & 0.070 & 2.14 & 0.021 & 0.180 & 6.90 & 0.062 \\
\hline Age & 0.010 & 1.46 & 0.003 & 0.007 & 0.89 & 0.002 & 0.016 & 2.52 & 0.005 \\
\hline $\mathrm{Age}^{2} \div 100$ & -0.002 & -0.33 & -0.001 & -0.008 & -1.01 & -0.002 & -0.008 & -1.29 & -0.003 \\
\hline Trust-1 & -0.076 & -8.25 & -0.026 & -0.055 & -5.82 & -0.017 & -0.029 & -3.87 & -0.010 \\
\hline Trust-2 & -0.038 & -4.03 & -0.013 & -0.033 & -3.47 & -0.010 & -0.020 & -2.72 & -0.007 \\
\hline Happiness & -0.016 & -2.22 & -0.006 & -0.005 & -0.66 & -0.002 & 0.000 & 0.05 & 0.000 \\
\hline Satisfaction & -0.226 & -12.97 & -0.079 & -0.161 & -7.63 & -0.048 & -0.141 & -8.82 & -0.048 \\
\hline Membership & -0.013 & -2.22 & -0.004 & -0.006 & -1.00 & -0.002 & 0.001 & 0.26 & 0.000 \\
\hline Density $\div 100$ & -0.279 & -2.05 & -0.097 & -0.219 & -1.57 & -0.065 & -0.282 & -2.05 & -0.095 \\
\hline Minority & 0.252 & 1.21 & 0.088 & 0.138 & 0.73 & 0.041 & 0.075 & 0.42 & 0.023 \\
\hline SD of random-effect & 0.004 & & & 0.000 & & & 0.006 & & \\
\hline sample size & 9,313 & & & 7,512 & & & 7,530 & & \\
\hline
\end{tabular}

endogeneity bias, since immigrants may avoid locations where anti-immigrant sentiment is more prevalent, so another set of results (available on request) includes estimates using the minority population density at the county level as an instrument for Minority, as in Dustman and Preston. ${ }^{48}$ Using the instrument leads to a moderate increase in the size and significance level of the Minority coefficients, but does not change any of the other results.

Conditional on these effects, there is a large and statistically significant difference between attitudes in archa constituencies and attitudes in non-archa constituencies. The first marginal effect for Archa-town in Table 2 implies that on average, the difference between the probability of a respondent in a non-archa constituency expressing anti-immigrant sentiment in 2010 and the probability of a respondent in an archa constituency expressing such sentiment is nearly 7 percentage points. (Compare this effect with Table 2, which reports an unconditional difference of 11 percentage points.) The next two marginal effects for Archa-town imply that the difference in the probability of ranking the BNP better than seventh is nearly 8 percentage points, and the difference in the probability of ranking the UKIP better than seventh is only slightly smaller. The Archa-town coefficients in Table 4 indicate effects in the 2005 data that are very similar and also statistically significant. The results consistently point to a significant difference between English towns with a Jewish heritage and those without: in the twenty-first

${ }^{48}$ Dustman and Preston 2001. 
TABLE 4 Determinants of Responses to Questions in the 2005 BES

\begin{tabular}{|c|c|c|c|c|c|}
\hline & \multicolumn{3}{|c|}{ Immigrant-issue-05 } & \multicolumn{2}{|c|}{ UKIP-feeling-05 } \\
\hline & \multicolumn{3}{|c|}{ Probit } & \multicolumn{2}{|c|}{ Tobit } \\
\hline & coeff. & $t$ ratio & m.e. & coeff. & $t$ ratio \\
\hline Archa-town & -0.204 & -2.30 & -0.061 & -0.623 & -2.23 \\
\hline Income & -0.206 & -0.68 & -0.062 & -3.341 & -3.64 \\
\hline If-kids & 0.011 & 0.20 & 0.003 & -0.041 & -0.23 \\
\hline If-beneficiary & -0.099 & -1.33 & -0.030 & 0.304 & 1.25 \\
\hline If-graduate & -0.426 & -7.17 & -0.128 & -1.413 & -7.68 \\
\hline If-low-quals & 0.168 & 3.70 & 0.050 & 0.395 & 2.53 \\
\hline If-widowed & -0.071 & -0.57 & -0.021 & -0.361 & -0.89 \\
\hline If-separated & -0.170 & -1.16 & -0.051 & -0.944 & -1.94 \\
\hline If-divorced & -0.059 & -0.77 & -0.018 & -0.434 & -1.64 \\
\hline If-single & -0.139 & -2.16 & -0.042 & 0.007 & 0.03 \\
\hline If-female & 0.040 & 0.94 & 0.012 & -0.055 & -0.40 \\
\hline If-religious & 0.054 & 1.26 & 0.016 & 0.535 & 3.82 \\
\hline Age & 0.017 & 1.60 & 0.005 & 0.012 & 0.36 \\
\hline Age $^{2} \div 100$ & -0.021 & -1.80 & -0.006 & -0.023 & -0.65 \\
\hline Trust-1 & -0.042 & -4.65 & -0.013 & -0.119 & -3.88 \\
\hline Satisfaction & -0.058 & -2.44 & -0.017 & -0.443 & -5.68 \\
\hline Membership & -0.004 & -0.54 & -0.001 & -0.019 & -0.70 \\
\hline Density $\div 100$ & -0.068 & -0.35 & -0.020 & -1.412 & -2.02 \\
\hline Minority & 0.156 & 0.49 & 0.047 & -1.772 & -1.35 \\
\hline SD of random effect & 0.003 & & & 0.565 & \\
\hline Sample size & 4,828 & & & 4,107 & \\
\hline
\end{tabular}

century, towns that welcomed medieval Jews show less anti-immigrant sentiment and less support for far-right parties.

Another striking feature of Tables 3 and 4 is the significance of the Trust and Satisfaction variables in all of the models. Table 3 shows that an increase in Trust-1 by one unit on its tenpoint scale reduces the probability of anti-immigrant sentiment by 3 percentage points, the probability of ranking the BNP better than seventh by 2 percentage points, and the probability of ranking the UKIP better than seventh by 1 percentage point. The effects of increases in Trust-2 are about half as large. An increase in Satisfaction by one unit on its four-point scale reduces the probability of anti-immigrant sentiment by 8 percentage points, the probability of ranking the BNP better than seventh by 5 percentage points, and the probability of ranking the UKIP better than seventh by 5 percentage points. Moreover, there are negative and significant coefficients on Trust-1 and Satisfaction in both of the models in Table 4. Trusting people are more positive about immigration and less likely to support a far-right party, as are those who are satisfied with the political system. These results suggest that the models in Tables 3 and 4 capture a large part of the variation in social capital (or at least that part of social capital relating to trust) and in the extent of alienation from the political process. Therefore, the significant differences between archa constituencies and non-archa constituencies are likely to be explained not by the intergenerational transmission of social capital, but by a more specific trait related to tolerance towards immigrants. Nevertheless, the fact that the twenty-first century immigrant communities are different from the medieval ones suggests that this trait is broader in scope than tolerance towards any one specific group. 


\section{Robustness Tests}

One potential concern with the interpretation of the results in Tables 3 and 4 is that the location of Jewish settlements is correlated with a number of medieval economic characteristics. In particular, settlements were in relatively large medieval towns with a royal mint: twenty-one out of the twenty-nine towns in Table 1 also appear in Dyer's list of forty-six towns with a large mint. ${ }^{49}$ The culture of towns that were already well established in the Middle Ages might differ from that of newer towns for reasons that have nothing to do with Jewish settlement. Similarly, the presence of a medieval royal mint might indicate a level of early financial development that reflects a particular type of culture. Another potential confounding factor is that there has been substantial variation in the rate of growth of towns' economies since 1290; this variation might be correlated both with the presence of an archa (reflecting a link between early economic development and subsequent growth) and with modern attitudes (since towns with high growth have also experienced more immigration).

Therefore, we present further results in which the sample is restricted to either (1) constituencies containing the largest medieval towns or (2) constituencies containing towns that had a royal mint. The list of large medieval towns is taken from Table 5 of Dyer, which is based on the 1377 Poll Tax; note that this sample excludes the smallest archa towns: Bedford, Devizes, Marlborough and Warwick. The list of medieval mints is taken from Table 1B of the Dyer article. In the results for the large medieval towns there are two additional explanatory variables: Growth-1, the rate of growth of the town population between 1377 and the mid-seventeenth century (the seventeenth century figures come from Langton), ${ }^{50}$ and Growth-2, the rate of growth of the town population between the mid-seventeenth century and 2010 (the 2010 figures come from the UK Census). ${ }^{51}$ Results for the large medieval town sample are reported in Table 5 (corresponding to Table 3) and Table 6 (corresponding to Table 4). ${ }^{52}$ Results for the medieval mints sample are reported in Table 7 (corresponding to Table 3). No results are reported for medieval mints and the 2005 BES data, because the sample size is well under 1,000 observations.

Although the sample in Table 5 is much smaller than the one in Table 3, the Archa-town coefficients in the two tables are very similar. Despite the reduction in sample size, all of the Table 5 coefficients are significantly different from zero at the 5 per cent level or less. Similarly, the coefficients in Table 6 are very similar to those in Table 4. However, the Table 6 sample comprises only about 1,000 observations and this does reduce the precision of the estimates: the Archa-town coefficients in Table 6 are significant at the 10 per cent level but not quite significant at the 5 per cent level. Table 7 shows that for two of the three BES 2010 variables (Immigrant-feeling-10 and UKIP-rank-10), restricting the sample to locations with medieval mints makes no substantial difference to the Archa-town estimates, and the effects are still significant at the 5 per cent level. The estimate for the third variable (BNP-rank-10) is smaller and statistically insignificant, but the sample here comprises only about 1,000 observations.

49 Dyer 2000.

50 Langton 2000.

51 There are a small number of cases in which the identity of the largest town in a constituency has changed over time; in these cases the population figures used at each point in time are for the largest town at that time. Population growth figures are not included in the medieval mint sample because in some cases the initial population figures are missing.

52 In cases where the reported standard deviation of the random effect is zero, the results have been produced using a pooled model with errors clustered at the constituency level. Otherwise, the tables report random-effects estimates. 
TAвLE 5 Determinants of Responses to Questions in the 2010 BES Medieval Towns Only

\begin{tabular}{|c|c|c|c|c|c|c|c|c|c|}
\hline & \multicolumn{3}{|c|}{ Immigrant-feeling-10 } & \multicolumn{3}{|c|}{ BNP-rank-10 } & \multicolumn{3}{|c|}{ UKIP-rank-10 } \\
\hline & \multicolumn{3}{|c|}{ Probit } & \multicolumn{3}{|c|}{ Ordered probit } & \multicolumn{3}{|c|}{ Ordered probit } \\
\hline & coeff. & $t$ ratio & m.e. & coeff. & $t$ ratio & m.e. & coeff. & $t$ ratio & m.e. \\
\hline Archa-town & -0.219 & -3.40 & -0.075 & -0.150 & -2.13 & -0.042 & -0.184 & -2.90 & -0.063 \\
\hline Income & -0.338 & -1.03 & -0.117 & -0.250 & -0.69 & -0.069 & -0.538 & -1.75 & -0.185 \\
\hline If-kids & 0.067 & 0.90 & 0.023 & 0.138 & 1.73 & 0.038 & -0.020 & -0.28 & -0.007 \\
\hline If-beneficiary & 0.066 & 0.54 & 0.023 & 0.105 & 0.81 & 0.029 & -0.016 & -0.15 & -0.006 \\
\hline If-graduate & -0.556 & -7.60 & -0.191 & -0.385 & -4.28 & -0.107 & -0.398 & -4.94 & -0.137 \\
\hline If-low-quals & 0.089 & 1.26 & 0.031 & 0.193 & 2.74 & 0.053 & 0.055 & 0.91 & 0.019 \\
\hline If-widowed & -0.441 & -2.71 & -0.152 & 0.259 & 1.33 & 0.072 & 0.153 & 1.28 & 0.052 \\
\hline If-separated & -0.250 & -1.32 & -0.086 & 0.057 & 0.26 & 0.016 & -0.131 & -0.77 & -0.045 \\
\hline If-divorced & -0.081 & -0.79 & -0.028 & -0.052 & -0.46 & -0.015 & -0.092 & -1.10 & -0.031 \\
\hline If-single & -0.117 & -1.25 & -0.040 & 0.002 & 0.01 & -0.000 & -0.025 & -0.29 & -0.009 \\
\hline If-female & -0.091 & -1.54 & -0.031 & -0.247 & -3.63 & -0.069 & -0.175 & -3.30 & -0.060 \\
\hline If-religious & 0.091 & 1.70 & 0.031 & 0.051 & 0.74 & 0.014 & 0.169 & 2.89 & 0.058 \\
\hline Age & 0.014 & 0.97 & 0.005 & 0.018 & 1.23 & 0.005 & 0.032 & 2.96 & 0.011 \\
\hline Age $^{2} \div 100$ & -0.004 & -0.25 & -0.001 & -0.014 & -0.98 & -0.004 & -0.023 & -2.13 & -0.008 \\
\hline Trust-1 & -0.078 & -3.72 & -0.027 & -0.060 & -2.92 & -0.017 & -0.012 & -0.68 & -0.004 \\
\hline Trust-2 & -0.027 & -1.46 & -0.009 & -0.022 & -0.96 & -0.006 & -0.035 & -2.11 & -0.012 \\
\hline Happiness & 0.001 & 0.07 & 0.000 & 0.000 & -0.02 & -0.000 & 0.007 & 0.49 & 0.003 \\
\hline Satisfaction & -0.257 & -6.99 & -0.088 & -0.239 & -5.16 & -0.066 & -0.176 & -4.98 & -0.060 \\
\hline Membership & -0.022 & -2.00 & -0.007 & -0.030 & -2.43 & -0.008 & -0.013 & -1.43 & -0.004 \\
\hline Density $\div 100$ & 0.386 & 1.58 & 0.133 & -0.154 & -0.52 & -0.043 & -0.114 & -0.46 & -0.039 \\
\hline Minority & -0.661 & -1.29 & -0.229 & 0.030 & 0.06 & 0.008 & 0.305 & 0.68 & 0.105 \\
\hline Growth-1 & 0.011 & 0.21 & 0.004 & -0.083 & -1.43 & -0.023 & -0.073 & -1.70 & -0.025 \\
\hline Growth-2 & -0.023 & -0.61 & -0.008 & -0.006 & -0.13 & -0.002 & -0.028 & -0.86 & -0.010 \\
\hline SD of random effect & 0.026 & & & 0.000 & & & 0.000 & & \\
\hline Sample size & 2,184 & & & 1,776 & & & 1,779 & & \\
\hline
\end{tabular}

Overall, the results in Tables 5-7 suggest that the link between modern attitudes and the presence of a medieval archa is robust.

\section{SUMMARY AND CONCLUSION}

On average, attitudes towards twenty-first century immigrants are significantly more positive among respondents in constituencies that were home to a medieval Jewish immigrant community. These constituencies also show less support for far-right political parties. These correlations suggest a positive effect of contact with medieval Jews that is consistent with evidence on modern intergroup contact and attitudes towards immigrants, ${ }^{53}$ while the persistence in regional variation over time is also a feature of other countries. ${ }^{54}$ However, the results here also suggest the persistence of an underlying cultural trait, of which attitudes towards a specific ethnic minority are just one expression, since the Jewish community was expelled from England in 1290 and there was no substantial foreign immigration until four

\footnotetext{
53 Schlueter and Scheepers 2010; Schneider 2008.

54 Jha 2013; Voigtländer and Voth 2013.
} 
TA в LE 6 Determinants of Responses to Questions in the 2005 BES Medieval Towns Only

\begin{tabular}{|c|c|c|c|c|c|}
\hline \multirow[b]{3}{*}{ Archa-town } & \multicolumn{3}{|c|}{ Immigrant-issue-05 } & \multicolumn{2}{|c|}{ UKIP-feeling-05 } \\
\hline & \multicolumn{3}{|c|}{ Probit } & \multicolumn{2}{|c|}{ Tobit } \\
\hline & -0.216 & -1.77 & -0.061 & -0.742 & -1.87 \\
\hline Income & -0.698 & -1.03 & -0.197 & -2.793 & -1.42 \\
\hline If-kids & -0.111 & -0.94 & -0.031 & 0.258 & 0.66 \\
\hline If-beneficiary & -0.203 & -1.14 & -0.057 & -0.082 & -0.15 \\
\hline If-graduate & -0.315 & -2.25 & -0.089 & -2.088 & -5.20 \\
\hline If-low-quals & 0.197 & 1.95 & 0.056 & 0.585 & 1.69 \\
\hline If-widowed & 0.183 & 0.75 & 0.052 & -0.490 & -0.49 \\
\hline If-separated & -0.408 & -1.27 & -0.115 & 0.504 & 0.51 \\
\hline If-divorced & -0.107 & -0.59 & -0.030 & -0.228 & -0.37 \\
\hline If-single & -0.419 & -2.92 & -0.118 & 0.591 & 1.39 \\
\hline If-female & 0.074 & 0.80 & 0.021 & -0.270 & -0.89 \\
\hline If-religious & 0.036 & 0.36 & 0.010 & 0.382 & 1.24 \\
\hline Age & 0.038 & 1.39 & 0.011 & 0.100 & 1.35 \\
\hline $\mathrm{Age}^{2} \div 100$ & -0.046 & -1.52 & -0.013 & -0.127 & -1.61 \\
\hline Trust-1 & -0.066 & -3.69 & -0.019 & -0.145 & -2.21 \\
\hline Satisfaction & 0.040 & 0.72 & 0.011 & 0.278 & -1.63 \\
\hline Membership & -0.013 & -0.94 & -0.004 & -0.077 & -1.41 \\
\hline Density $\div 100$ & 0.378 & 0.96 & 0.107 & -1.528 & -0.99 \\
\hline Minority & -0.965 & -1.09 & -0.273 & -1.907 & -0.58 \\
\hline Growth-1 & 0.039 & 0.43 & 0.011 & -0.277 & -0.95 \\
\hline Growth-2 & -0.041 & -0.69 & -0.011 & -0.093 & -0.49 \\
\hline SD of random effect & 0.000 & & & 0.415 & \\
\hline Sample size & 1,063 & & & 921 & \\
\hline
\end{tabular}

centuries later. The results also imply a substantial amount of cultural heterogeneity across England that is distinct from the North-South or rural-urban divides.

In describing these results, we recognize that estimating the relationship between regional variation in the twenty-first century and regional variation in the thirteenth century is in some ways less satisfactory than a statistical analysis tracking attitudes across all nine centuries unfortunately, there were no social attitude surveys in medieval England! There is no direct evidence for the mechanisms, which this article suggests as an explanation for the connection between the twenty-first century variation and the thirteenth century variation. Nevertheless, the strong correlation between twenty-first century attitudes and the distribution of medieval Jews is robust to conditioning on a wide range of contemporary and historical characteristics, so it is not obvious what other explanation there could be for this correlation.

Our results might suggest a certain pessimism about the chances of success of attempts to reduce tensions between indigenous and immigrant groups. However, the results can be seen in a more positive light. While Rappaport finds that ethnic heterogeneity reduces economic growth in US cities, and Glaeser, Scheinkman and Shleifer find that more ethnic segregation in cities is good for growth, ${ }^{55}$ our results imply that certain cities have an inherent ability to cope more easily with ethnic diversity. Policies that persuade such cities to take advantage of this ability by encouraging immigration or investment in activities that require more racial tolerance

55 Glaeser, Scheinkman, and Shleifer 1995; Rappaport 1999. 
TABLE 7 Determinants of Responses to Questions in the 2010 BES Locations with Medieval Mints Only

\begin{tabular}{|c|c|c|c|c|c|c|c|c|c|}
\hline & \multicolumn{3}{|c|}{ Immigrant-feeling-10 } & \multicolumn{3}{|c|}{ BNP-rank-10 } & \multicolumn{3}{|c|}{ UKIP-rank-10 } \\
\hline & \multicolumn{3}{|c|}{ Probit } & \multicolumn{3}{|c|}{ Ordered probit } & \multicolumn{3}{|c|}{ Ordered probit } \\
\hline & coeff. & $t$ ratio & m.e. & coeff. & $t$ ratio & m.e. & coeff. & $t$ ratio & m.e. \\
\hline Archa-town & -0.229 & -2.69 & -0.077 & -0.124 & -1.14 & -0.032 & -0.181 & -2.40 & -0.063 \\
\hline Income & 0.355 & 0.87 & 0.120 & 0.564 & 1.21 & 0.145 & 0.124 & 0.33 & 0.043 \\
\hline If-kids & 0.037 & 0.38 & 0.012 & 0.065 & 0.66 & 0.017 & 0.037 & 0.42 & 0.013 \\
\hline If-beneficiary & 0.196 & 1.19 & 0.066 & 0.355 & 2.29 & 0.091 & 0.084 & 0.56 & 0.029 \\
\hline If-graduate & -0.524 & -6.00 & -0.177 & -0.388 & -3.28 & -0.100 & -0.413 & -3.78 & -0.143 \\
\hline If-low-quals & 0.222 & 2.19 & 0.075 & 0.169 & 1.95 & 0.044 & -0.078 & -0.89 & -0.027 \\
\hline If-widowed & -0.827 & -2.81 & -0.280 & 0.304 & 1.30 & 0.078 & -0.163 & -0.80 & -0.056 \\
\hline If-separated & -0.441 & -1.85 & -0.149 & 0.193 & 0.66 & 0.050 & 0.031 & 0.10 & 0.011 \\
\hline If-divorced & -0.351 & -2.40 & -0.119 & -0.168 & -0.95 & -0.043 & -0.127 & -0.93 & -0.044 \\
\hline If-single & -0.341 & -2.75 & -0.115 & -0.392 & -2.50 & -0.101 & -0.041 & -0.34 & -0.014 \\
\hline If-female & -0.054 & -0.69 & -0.018 & -0.272 & -2.70 & -0.070 & -0.125 & -1.61 & -0.043 \\
\hline If-religious & 0.280 & 3.53 & 0.095 & -0.056 & -0.54 & -0.014 & 0.194 & 2.01 & 0.067 \\
\hline Age & -0.005 & -0.27 & -0.002 & 0.052 & 2.09 & 0.013 & 0.015 & 0.79 & 0.005 \\
\hline $\mathrm{Age}^{2} \div 100$ & 0.017 & 0.82 & 0.006 & -0.044 & -1.74 & -0.011 & -0.003 & -0.17 & -0.001 \\
\hline Trust-1 & -0.096 & -4.09 & -0.033 & -0.055 & -2.21 & -0.014 & -0.051 & -2.41 & -0.018 \\
\hline Trust-2 & -0.038 & -1.46 & -0.013 & -0.043 & -1.86 & -0.011 & -0.038 & -1.81 & -0.013 \\
\hline Happiness & -0.023 & -1.08 & -0.008 & 0.004 & 0.17 & 0.001 & 0.008 & 0.38 & 0.003 \\
\hline Satisfaction & -0.144 & -3.35 & -0.049 & -0.153 & -2.82 & -0.039 & -0.089 & -2.02 & -0.031 \\
\hline Membership & 0.009 & 0.53 & 0.003 & -0.027 & -1.62 & -0.007 & -0.027 & -1.67 & -0.009 \\
\hline Density $\div 100$ & 0.541 & 1.67 & 0.183 & -0.256 & -0.67 & -0.066 & -0.946 & -2.89 & -0.328 \\
\hline Minority & -0.734 & -1.78 & -0.248 & 0.008 & 0.01 & 0.002 & 1.115 & 1.71 & 0.386 \\
\hline $\mathrm{SD}$ of random effect & 0.001 & & & 0.000 & & & 0.000 & & \\
\hline Sample size & 1,216 & & & 959 & & & 961 & & \\
\hline
\end{tabular}

(such as international trade and tourism) could promote economic growth at the local and national levels.

\section{REFERENCES}

Acharya, Avidit, Matthew Blackwell, and Maya Sen. 2014. The Political Legacy of American Slavery. Mimeo: Stanford University, Available from http://web.stanford.edu/ avidit/slavery.pdf, accessed 31 March 2015.

Alesina, Alberto, Paola Giuliano, and Nathan Nunn. 2013. On the Origins of Gender Roles: Women and the Plough. Quarterly Journal of Economics 128:469-530.

Allport, Gordon W. 1954. The Nature of Prejudice. Reading, MA: Addison-Wesley.

Axelrod, Robert. 1997. The Dissemination of Culture: A Model with Local Convergence and Global Polarization. Journal of Conflict Resolution 41:203-26.

Bale, Anthony P. 2000. Richard of Devizes and Fictions of Judaism. Jewish Culture and History 3:55-72.

Becchetti, Leonardo, Fiammetta Rossetti, and Stefano Castriota. 2010. Real Household Income and Attitude Toward Immigrants: An Empirical Analysis. Journal of Socio-Economics 39:81-8.

Borisyuk, Galina, Colin Rallings, Michael Thrasher, and Henk van der Kolk. 2007. Voter Support for Minor Parties Assessing the Social and Political Context of Voting at the 2004 European Elections in Greater London. Party Politics 13:669-93. 
Bowyer, Benjamin. 2008. Local Context and Extreme Right Support in England: The British National Party in the 2002 and 2003 Local Elections. Electoral Studies 27:611-20.

Brand, Paul. 2003. The Jewish Community of England in the Records of English Royal Government. In The Jews in Medieval Britain: Historical, Literary, and Archaeological Perspectives, edited by Patricia Skinner, 73-85. Woodbridge, UK: Boydell Press.

Brown, Reva Berman, and Sean McCartney. 2005. The Exchequer of the Jews Revisited: The Operation and Effect of the Scaccarium Judeorum. Medieval History Journal 8:303-22.

Carey, Sean, and Andrew Geddes. 2010. Less Is More: Immigration and European Integration at the 2010 General Election. Parliamentary Affairs 63:849-65.

Cavalli-Sforza, Luca L. 1981. Cultural Transmission and Evolution: A Quantitative Approach. Princeton, NJ: Princeton University Press.

Cavalli-Sforza, Luca L., and Marcus W. Feldman. 1973. Models for Cultural Inheritance I. Group Mean and Within Group Variation. Theoretical Population Biology 4:42-55.

Cavalli-Sforza, Luca L., Marcus W. Feldman, Kuang-Ho Chen, and Sanford M. Dornbusch. 1982. Theory and Observation in Cultural Transmission. Science 218:19-27.

Cutts, David, Robert Ford, and Matthew J. Goodwin. 2011. Anti-Immigrant, Politically Disaffected or Still Racist After All? Examining the Attitudinal Drivers of Extreme Right Support in Britain in the 2009 European Elections. European Journal of Political Research 50:418-40.

Dalton, John T., and Tin Cheuk Leung. 2011. Why is Polygyny More Prevalent in Western Africa? An African Slave Trade Perspective. Munich Personal RePEc Archive Paper 32598. Available from http://mpra.ub.uni-muenchen.de/32598/, accessed 31 March 2015.

Dovidio, John F., Peter E. Glick, and Laurie A. Rudman. 2005. On the Nature of Prejudice: Fifty Years After Allport. Oxford, UK: Blackwell Publishing.

Dustmann, Christian, and Ian Preston. 2001. Attitudes to Ethnic Minorities, Ethnic Context and Location Decisions. Economic Journal 111:353-73.

Dustmann, Christian, and Ian P. Preston. 2007. Racial and Economic Factors in Attitudes to Immigration. BE Journal of Economic Analysis \& Policy 7.

Dyer, Alan. 2000. Ranking Lists of English Medieval Towns. In The Cambridge Urban History of Britain, Vol. I: 600-1540, edited by David M. Palliser, Peter Clark and Martin J. Daunton, 747-70. Cambridge, UK: Cambridge University Press.

Ehrlich, Paul R., and Simon A. Levin. 2005. The Evolution of Norms. PLoS Biology 3:e194.

Epstein, Joshua M., and Robert Axtell. 1996. Growing Artificial Societies: Social Science from the Bottom Up. New York: Brookings Institution Press.

Facchini, Giovanni, Anna M. Mayda, and Mariapia Mendola. 2013. What Drives Individual Attitudes Towards Immigration in South Africa? Review of International Economics 21: 326-41.

Fertig, Michael, and Christoph M. Schmidt. 2011. Attitudes Towards Foreigners and Jews in Germany: Identifying the Determinants of Xenophobia in a Large Opinion Survey. Review of Economics of the Household 9:99-128.

Fischer, David Hackett. 1989. Albion's Seed: Four British Folkways in America. Oxford, UK: Oxford University Press.

Ford, Robert, and Matthew J. Goodwin. 2010. Angry White Men: Individual and Contextual Predictors of Support for the British National Party. Political Studies 58:1-25.

Gang, Ira N., Francisco Rivera-Batiz, and Myeong-Su Yun. 2002. Economic Strain, Ethnic Concentration and Attitudes Towards Foreigners in the European Union. Discussion Paper No. 578. Bonn: IZA.

Glaeser, Edward L., José A. Scheinkman, and Andrei Shleifer. 1995. Economic Growth in a Cross-Section of Cities. Journal of Monetary Economics 36:117-43.

Grosfeld, Irena, and Ekaterina Zhuravskaya. 2013. Persistent Effects of Empires: Evidence from the Partitions of Poland. Discussion Paper No. 9371. London: Centre for Economic Policy Research.

Grosjean, Pauline. 2014. A History of Violence: The 'Culture of Honor' as a Determinant of Homicide. Journal of the European Economic Association 12:1285-316. 
Guiso, Luigi, Paola Sapienza, and Luigi Zingales. 2008. Long Term Persistence. Working Paper No. w14278. Cambridge, MA: NBER.

Hainmueller, Jens, and Michael J. Hiscox. 2010. Attitudes Toward Highly Skilled and Low-Skilled Immigration: Evidence from a Survey Experiment. American Political Science Review 104: 61-84.

Hillaby, Joe. 2003. Jewish Colonisation in the Twelfth Century. In The Jews in Medieval Britain: Historical, Literary, and Archaeological Perspectives, edited by Patricia Skinner, 15-41. Woodbridge, UK: Boydell Press.

Hillaby, Joe, and Caroline Hillaby, eds. 2013. The Palgrave Dictionary of Medieval Anglo-Jewish History. London: Palgrave Macmillan.

Iannaccone, Laurence R., and Michael D. Makowsky. 2007. Accidental Atheists? Agent-Based Explanations for the Persistence of Religious Regionalism. Journal for the Scientific Study of Religion 46:1-16.

Jha, Saumitra. 2013. Trade, Institutions, and Ethnic Tolerance: Evidence from South Asia. American Political Science Review 107:806-32.

Katz, David S. 1994. The Jews in the History of England, 1485-1850. Oxford, UK: Clarendon Press.

Langmuir, Gavin I. 1963. The Jews and the Archives of Angevin England: Reflections on Medieval AntiSemitism. Traditio 19:183-244.

Langton, Jack. 2000. Urban Growth and Economic Change: From the Late Seventeenth Century to 1841. In The Cambridge Urban History of Britain, Vol. II: 1540-1840, edited by Peter Clark, 453-90. Cambridge, UK: Cambridge University Press.

Malchow-Møller, Nikolaj, Jakob Roland Munch, Sanne Schroll, and Jan Rose Skaksen. 2008. Attitudes Towards Immigration - Perceived Consequences and Economic Self-Interest. Economics Letters 100:254-7.

- 2009. Explaining Cross-Country Differences in Attitudes Towards Immigration in the EU-15. Social Indicators Research 91:371-90.

McFarland, Sam. 2010. Authoritarianism, Social Dominance, and Other Roots of Generalized Prejudice. Political Psychology 31:453-77.

McLaren, Lauren, and Mark Johnson. 2007. Resources, Group Conflict and Symbols: Explaining AntiImmigration Hostility in Britain. Political Studies 55:709-32.

Menache, Sophia. 1997. Matthew Paris's Attitudes Toward Anglo-Jewry. Journal of Medieval History 23:139-62.

Miguet, Florence. 2008. Voting About Immigration Policy: What Does the Swiss experience Tell Us? European Journal of Political Economy 24:628-41.

Miguet, Florence, and Tobias Müller. 2007. Determinants of Individual Attitudes Towards Immigration. The Role of Trust. Paper prepared for the 29th Congress of the European Economic Association and the 68th European Meeting of the Econometric Society, Budapest.

Mundill, Robert R. 1988. The Jews in England 1272-1290. Ph.D. dissertation, University of St Andrews, Scotland.

—. 2010. The King's Jews: Money, Massacre and Exodus in Medieval England. London: Continuum Books.

Nunn, Nathan, and Leonard Wantchekon. 2009. The Slave Trade and the Origins of Mistrust in Africa. Working Paper No. w14783. Cambridge, MA: NBER.

O'Rourke, Kevin H., and Richard Sinnott. 2006. The Determinants of Individual Attitudes Towards Immigration. European Journal of Political Economy 22:838-61.

Ortega, Francesc, and Javier G. Polavieja. 2012. Labor-Market Exposure as a Determinant of Attitudes Toward Immigration. Labour Economics 19:298-311.

Pettigrew, Thomas F., and Linda R. Tropp. 2006. A Meta-Analytic Test of Intergroup Contact Theory. Journal of Personality and Social Psychology 90:751-83.

—. 2012. When Groups Meet: The Dynamics of Intergroup Contact. New York: Psychology Press.

Pettigrew, Thomas F., Ulrich Wagner, and Oliver Christ. 2007. Who Opposes Immigration? Du Bois Review: Social Science and Research on Race 4:19-39. 
Raijman, Rebeca, and Moshe Semyonov. 2004. Perceived Threat and Exclusionary Attitudes Towards Foreign Workers in Israel. Ethnic and Racial Studies 27:780-99.

Rappaport, Jordan. 1999. Local Growth Empirics. CID Working Paper No. 23. Cambridge, MA: Harvard University.

Rokéah, Zefira E. 2001. An Anglo-Jewish Assembly or Mini-Parliament in 1287. Thirteenth Century England 8:71-96.

Rustenbach, Elisa. 2010. Sources of Negative Attitudes Toward Immigrants in Europe: A Multi-Level Analysis 1. International Migration Review 44:53-77.

Scheil, Andrew P. 2004. The Footsteps of Israel: Understanding Jews in Anglo-Saxon England. Ann Arbor: University of Michigan Press.

Schlueter, Elmar, and Peer Scheepers. 2010. The Relationship Between Outgroup Size and Anti-Outgroup Attitudes: A Theoretical Synthesis and Empirical Test of Group Threat and Intergroup Contact Theory. Social Science Research 39:285-95.

Schneider, Silke L. 2008. Anti-Immigrant Attitudes in Europe: Outgroup Size and Perceived Ethnic Threat. European Sociological Review 24:53-67.

Skinner, Patricia. 2003. Introduction: Jews in Medieval Britain and Europe. In The Jews in Medieval Britain: Historical, Literary, and Archaeological Perspectives, edited by Patricia Skinner, 1-11. Woodbridge, UK: Boydell Press.

Stacey, Robert C. 2003. The English Jews Under Henry III. In The Jews in Medieval Britain: Historical, Literary, and Archaeological Perspectives, edited by Patricia Skinner, 41-55. Woodbridge, UK: Boydell Press.

Thomsen, Lotte, Eva G.T. Green, and Jim Sidanius. 2008. We Will Hunt Them Down: How Social Dominance Orientation and Right-Wing Authoritarianism Fuel Ethnic Persecution of Immigrants in Fundamentally Different Ways. Journal of Experimental Social Psychology 44:1455-64.

Voigtländer, Nico, and Hans-Joachim Voth. 2013. Persecution Perpetuated: The Medieval Origins of Anti-Semitic Violence in Nazi Germany. Quarterly Journal of Economics 127:1339-92.

Whitaker, Richard, and Philip Lynch. 2011. Explaining Support for the UK Independence Party at the 2009 European Parliament Elections. Journal of Elections, Public Opinion and Parties 21:359-79. 